\title{
Surface Topographies of Two-Year Coupons of Titanium Grade 16 from Long-Term Testing
}

\author{
P. J. Bedrossian
}

December 28, 1999

U.S. Department of Energy

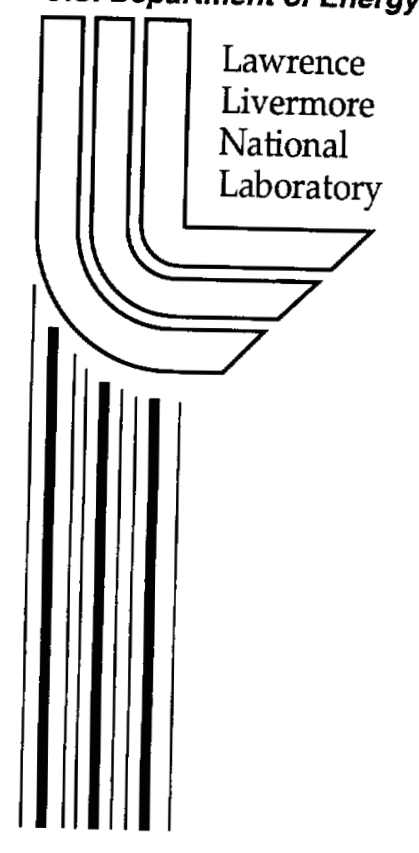




\section{DISCLAIMER}

This document was prepared as an account of work sponsored by an agency of the United States Government. Neither the United States Government nor the University of California nor any of their employees, makes any warranty, express or implied, or assumes any legal liability or responsibility for the accuracy, completeness, or usefulness of any information, apparatus, product, or process disclosed, or represents that its use would not infringe privately owned rights. Reference herein to any specific commercial product, process, or service by trade name, trademark, manufacturer, or otherwise, does not necessarily constitute or imply its endorsement, recommendation, or favoring by the United States Government or the University of California. The views and opinions of authors expressed herein do not necessarily state or reflect those of the United States Government or the University of California, and shall not be used for advertising or product endorsement purposes.

This work was performed under the auspices of the U.S. Department of Energy by the University of California, Lawrence Livermore National Laboratory under Contract No. W-7405-Eng-48.

This report has been reproduced directly from the best available copy.

Available electronically at http://www.doc.gov/bridge

Available for a processing fee to U.S. Department of Energy

And its contractors in paper from

U.S. Department of Energy

Office of Scientific and Technical Information P.O. Box 62

Oak Ridge, TN 37831-0062

Telephone: (865) 576-8401

Facsimile: (865) 576-5728

E-mail: reports@adonis.osti.gov

Available for the sale to the public from

U.S. Department of Commerce

National Technical Information Service

5285 Port Royal Road

Springfield, VA 22161

Telephone: (800) 553-6847

Facsimile: (703) 605-6900

E-mail: orders@ntis.fedworld.gov

Online ordering: http://www.ntis.gov/ordering.htm

OR

Lawrence Livermore National Laboratory

Technical Information Department's Digital Library

http://www.llnl.gov/tid/Library.html 


\title{
Surface Topographies of Two-Year Coupons of Titanium Grade 16 from Long-Term Testing
}

\author{
Peter J. Bedrossian
}

Division of Materials Science \& Technology and

Yucca Mountain Site Characterization Project

Lawrence Livermore National Laboratory, Livermore CA 94551

28 December 1999

\begin{abstract}
Using an Atomic Force Microscope, we have examined the surface topographies associated with crevice coupons representing the six classes of coupons of Titanium Grade 16 removed from Long-Term Corrosion testing after two years of immersion. Only on coupons removed from Simulated Concentrated Well Water do we observe features which are likely to represent embryonic pit formation. The coupons removed from the Simulated Acidified Well Water were too rough to yield representative measurements.
\end{abstract}




\section{Introduction}

Titanium Grade 16 is one of the commercial metal alloys which has been included in Lawrence Livermore's Long-Term Corrosion Testing Program, for evaluation of its suitability of possible inclusion in the proposed geological repository. Most of the coupons which are removed from Long-Term testing are routinely subjected to weightloss measurements. However, one coupon representative of each class of environmental conditions has been preserved for surface analytical measurements. While the weight loss typically provides a single number characterizing the total loss of material, it is necessary to use some form of microscopy to identify indications of localized corrosion. In this study, we have applied Atomic Force Microscopy (AFM) because of its subnanometer, vertical resolution.

A total of six coupons of Titanium Grade 16 were made available for this study: one each from Simulated Concentrated Well Water (SCW), Simulated Diluted Well Water (SDW), and Simulated Acidified Well Water (SAW), at 60C and 90C. After their immersion in the aqueous baths for two years, the samples were rinsed in de-ionized water. Prior to AFM imaging, the scale and salt deposits were removed by wiping with a damp, cotton swab.

This study is a follow-up to a previous report detailing AFM analyses of one-year coupons of both Grades 12 and Grades 16 of titanium, and the associated, unexposed control coupons. ${ }^{1}$ Details of the alloy composition and the electrolyte compositions are contained in that report.

\section{Methods}

The procedures for AFM analysis follow the description included in reference [1]. The collection of the data included in this report is included in Notebook YMP-SN-00427 and is governed by Activity Plan AP-E-20-69.

AFM images are presented below with a linear mapping identifying grey scale with height. The mapping, or "look-up table" associated with each image is unique, because the maximum grey scale is applied to the maximum range of each image. The vertical band appearing to the right of each image represents the look-up table used to display its associated image. Depths of specific features are shown in line profiles which are derived from the AFM images in which the features appear. The file numbers corresponding to the notebook entries and the sample serial numbers appear the captions for the figures below.

\footnotetext{
${ }^{1}$ P. Bedrossian, "Passive Film Morphology of One-Year Titanium Coupons from Long-Term Corosion Testing," UCRL ID-136008 (1999).
} 


\section{Results}

A previous study, [1], identified what appeared to be cracking in the passive films of some titanium coupons exposed to aqueous baths in Long-Term testing for one year but did not identify incipient pitting on those coupons.

Examination of the two year coupons reveals substantial evolution in the surface morphologies of titanium test coupons under some of the conditions studied here. Depressions which strongly suggest pit embryos have appeared throughout the crevice exterior of the coupon removed from $90 \mathrm{C} \mathrm{SCW}$, as in Figure 1 (outside the crevice), Figure 2, Figure 3, and Figure 4. The line profile in Figure 5 shows a profile of one of these pit-like features which has reached a depth of approximately $800 \mathrm{~nm}$. Immediately inside the crevice of the same coupon, we do not observe the pit embryos (Figure 1-left side, and Figure 6). However, more widespread attack appears deeper in the crevice (Figure 7 and Figure 9 and associated line profiles).

Of the remaining data, Figure 12, acquired from the $60 \mathrm{C} \mathrm{SCW}$ coupon, seems to show a less advanced stage of pit evolution than has occurred on the $90 \mathrm{C} \mathrm{SCW}$ coupon. The subsequent figures show isolated depressions on 60C and 90C SDW coupons, which we cannot definitively associate with corrosion in this work.

The coupons removed from 60 and $90 \mathrm{C}$ SAW were too rough for us to acquire a representative data set.

\section{Summary}

The test matrix covered by this report includes the following conditions and samples:

\begin{tabular}{l|ll|ll} 
& \multicolumn{2}{|c|}{$90 \mathrm{C}$} & \multicolumn{2}{c}{$60 \mathrm{C}$} \\
\hline SAW & FCE046 & Too Rough & FCE016 & Too Rough \\
SDW & FCE172 & Not definitive & FCE136 & Not definitive \\
SCW & FCE106 & Incipient Pitting Likely & FCE076 & Incipient Pitting Likely
\end{tabular}

We suggest that subsequent studies address the kinetics of pit evolution, including growth and stifling. Alternative methodologies will be required to assess the reason that the SAW coupons were too rough for AFM analysis.

\section{Acknowledgments}

The author is grateful to David Fix for assistance with the AFM measurements. This work was performed at Lawrence Livermore National Laboratory under the auspices of the US-DOE under Contract W-7405-Eng-48, and was partially supported by the Yucca Mountain Site Characterization Project. 


\section{List of Figures}

Figure 1: AFM image at the crevice boundary on the obverse side of coupon FCE106, immersed in $90 \mathrm{C} \mathrm{SCW}$ for 2 years. The right half of the image is outside the crevice, and the left half is inside the crevice. (File 991027a.004).

Figure 2: AFM image acquired $100 \mu \mathrm{m}$ outside the crevice boundary on the obverse side of coupon FCE106, immersed in 90C SCW for 2 years. (File 991027a.005)........... 6

Figure 3: AFM image acquired $1 \mathrm{~mm}$ outside the crevice boundary on the obverse side of coupon FCE106, immersed in 90C SCW for 2 years. (File 991027a.007) .............. 7

Figure 4: $25-\mu \mathrm{m}$ detail of the central region of Figure 3. (File 991027a.008) ............... 8

Figure 5: Profile of the depression in the lower left corner of the previous figure. ......... 9

Figure 6: AFM image acquired 250 $\mathrm{m}$ inside the crevice on the obverse side of coupon FCE106, immersed in 90C SCW for 2 years. (File 991127a.009)

Figure 7: AFM image acquired 700 $\mathrm{m}$ inside the crevice on the obverse side of coupon FCE106, immersed in 90C SCW for 2 years. (File 991127a.011) ....................... 11

Figure 8: Profile through a depression in the lower right in the previous figure. ........... 12

Figure 9: AFM image acquired $1.0 \mathrm{~mm}$ inside the crevice on the obverse side of coupon FCE106, immersed in 90C SCW for 2 years. (File 991127a.012) ....................... 13

Figure 10: Profile through a depression in the upper right in the previous figure. .......... 14

Figure 11: AFM image acquired inside the crevice on the obverse side of coupon FCE076, immersed in 60C SCW for 2 years. (File 991103a.003)

Figure 12: AFM image acquired at the crevice boundary on the obverse side of coupon FCE076, immersed in $60 \mathrm{C} \mathrm{SCW}$ for 2 years. The top is outside the crevice, and the lower half is inside the crevice.(File 991103a.005)

Figure 13: AFM image acquired outside the crevice on the obverse side of coupon FCE076, immersed in 60C SCW for 2 years. (File 991 103a.007) ........................ 17

Figure 14: Profile plot across the prominent depression in the previous figure.............. 18

Figure 15: AFM image acquired outside the crevice on the obverse side of coupon

FCE076, immersed in 60C SCW for 2 years. (File 991103a.009) ........................... 19

Figure 16: Profile plot across the prominent depression in the previous figure............... 20

Figure 17: AFM image acquired outside the crevice on the obverse side of coupon FCE172, which was immersed in 90C SDW for 2 years. (File 991026a.010)....... 21

Figure 18: AFM image acquired inside the crevice of coupon FCE136, immersed in 60C SDW for 2 years. (File 991101a.001) .............................................................. 22

Figure 19: AFM image acquired outside the crevice of coupon FCE136, immersed in 60C SDW for 2 years. (File 991101a.001) ......................................................... 23 


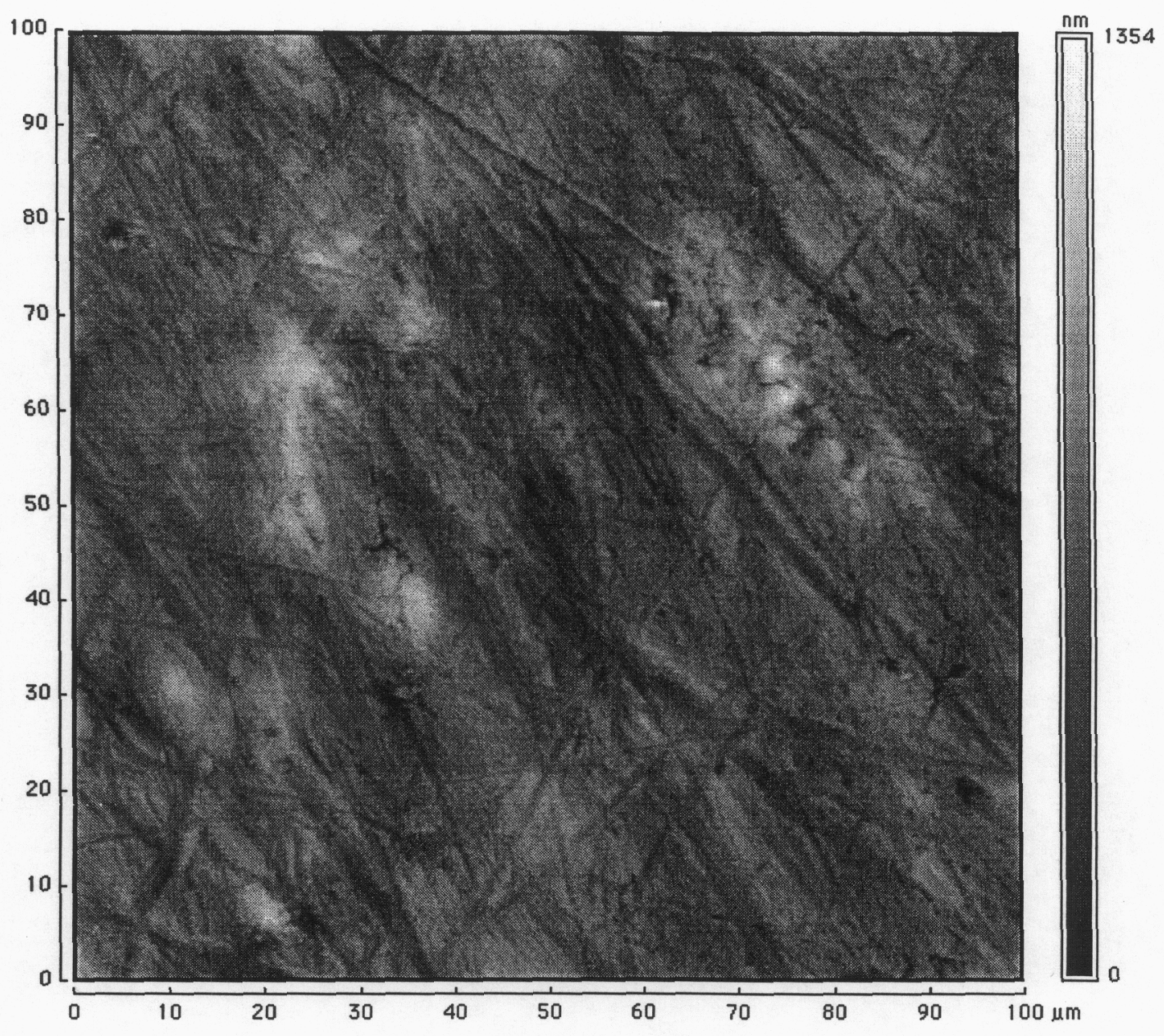

Figure 1: AFM image at the crevice boundary on the obverse side of coupon FCE106, immersed in $90 \mathrm{C} \mathrm{SCW}$ for 2 years. The right half of the image is outside the crevice, and the left half is inside the crevice. (File 991027a.004) 


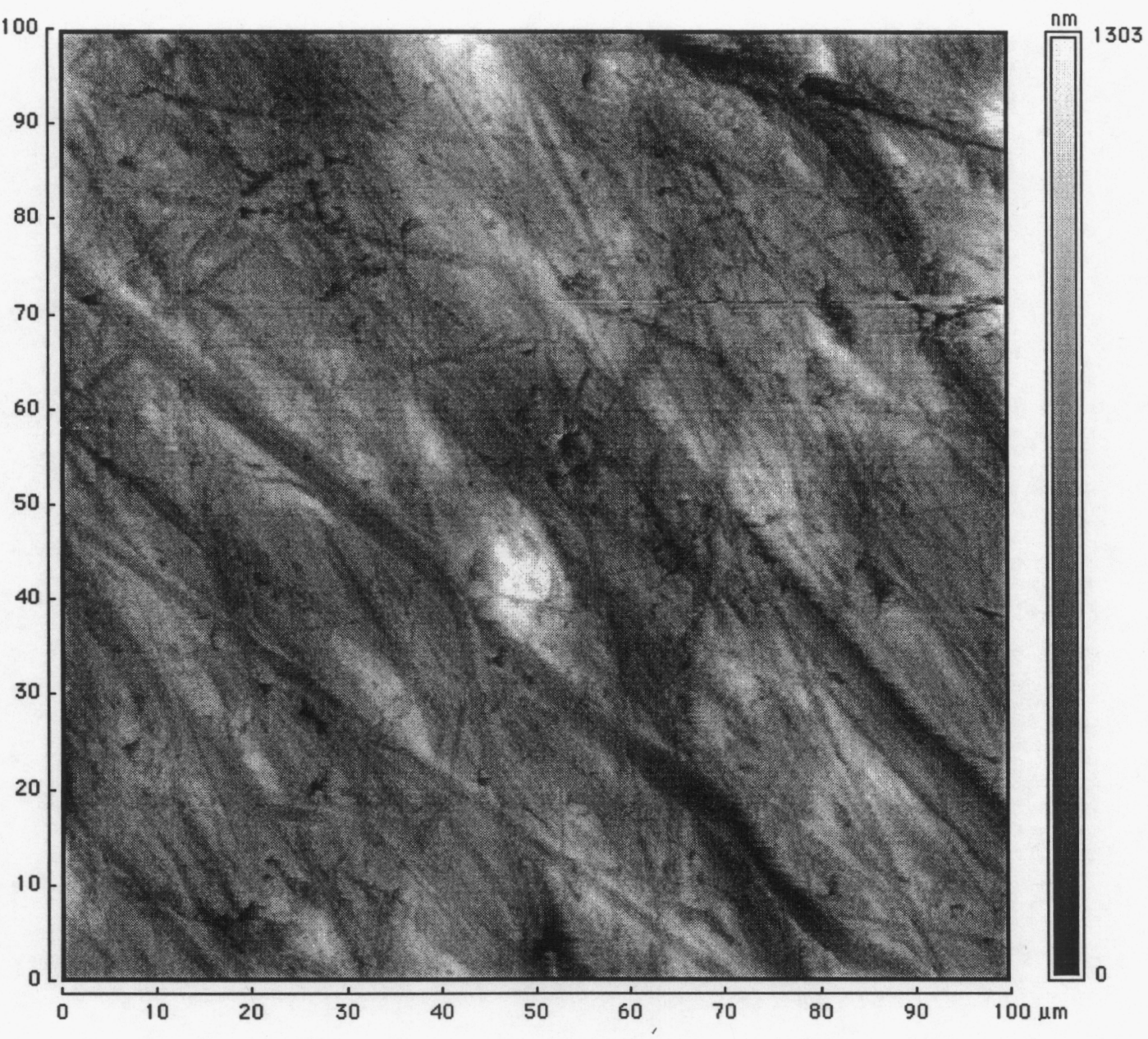

Figure 2: AFM image acquired $100 \mu \mathrm{m}$ outside the crevice boundary on the obverse side of coupon FCE106, immersed in 90C SCW for 2 years. (File 991027a.005) 


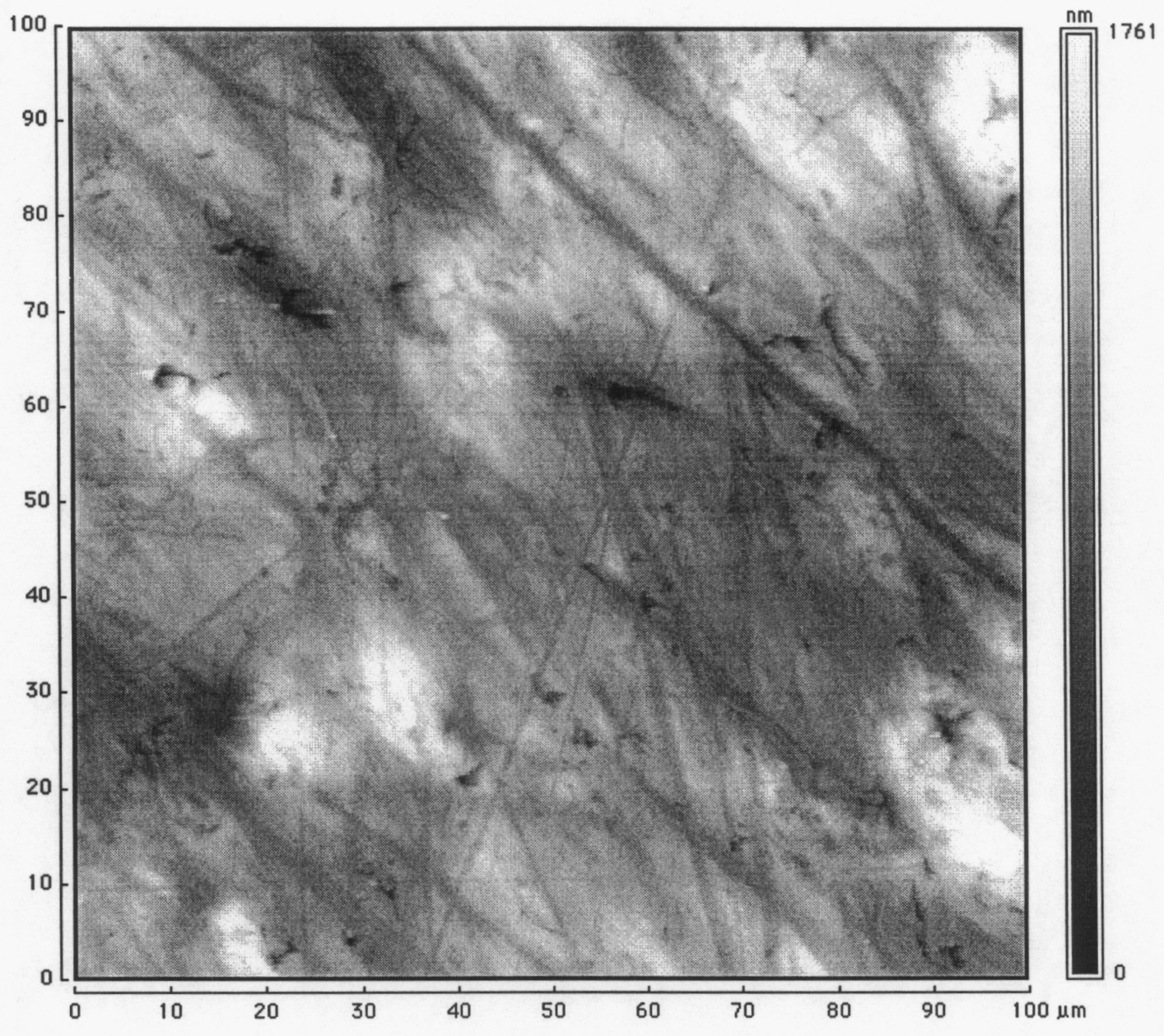

Figure 3: AFM image acquired $1 \mathrm{~mm}$ outside the crevice boundary on the obverse side of coupon FCE106, immersed in 90C SCW for 2 years. (File 991027a.007) 


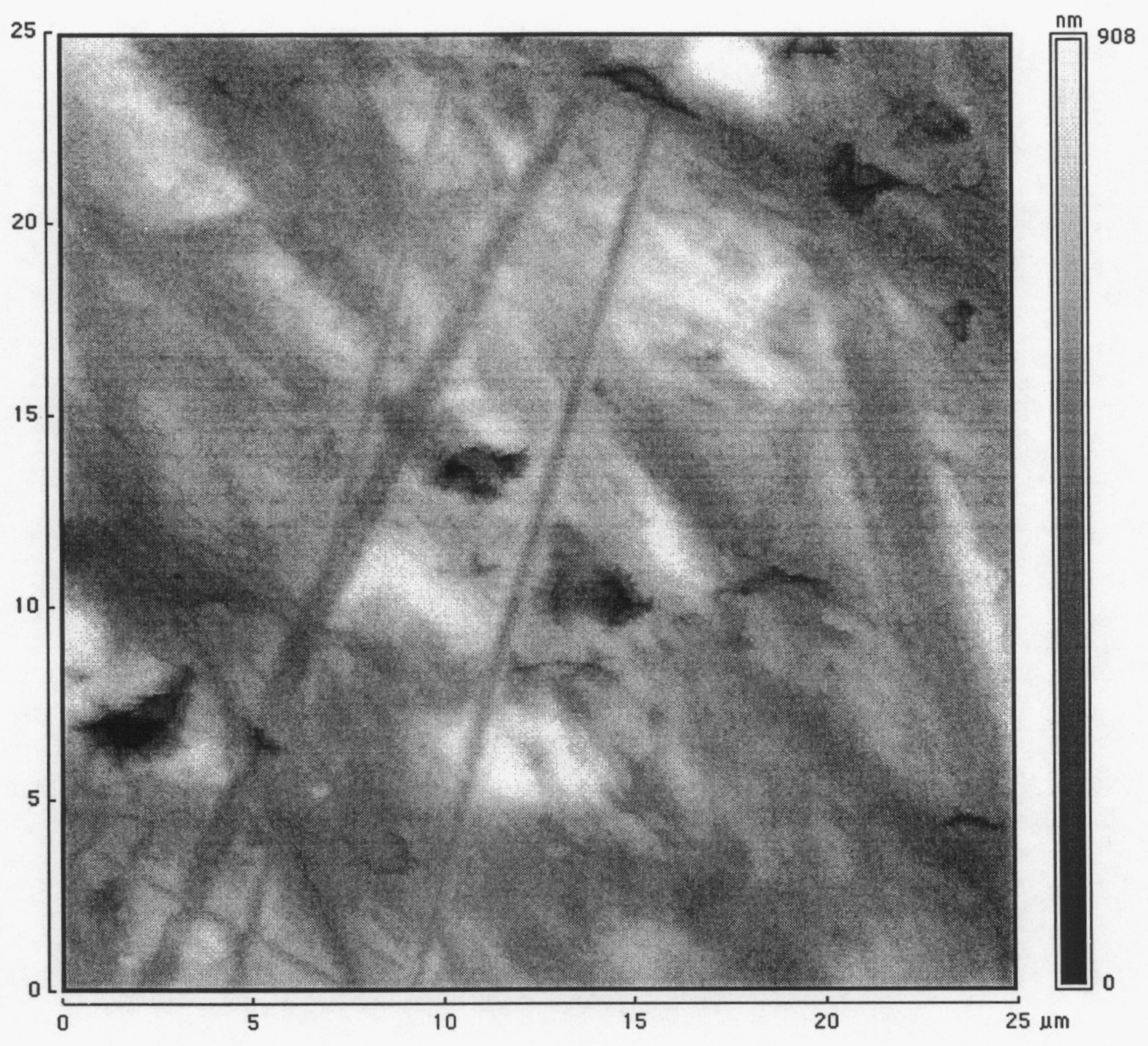

Figure 4: $25-\mu \mathrm{m}$ detail of the central region of Figure 3: AFM image acquired $1 \mathrm{~mm}$ outside the crevice boundary on the obverse side of coupon FCE106, immersed in 90C SCW for 2 years. (File 991027a.008) 


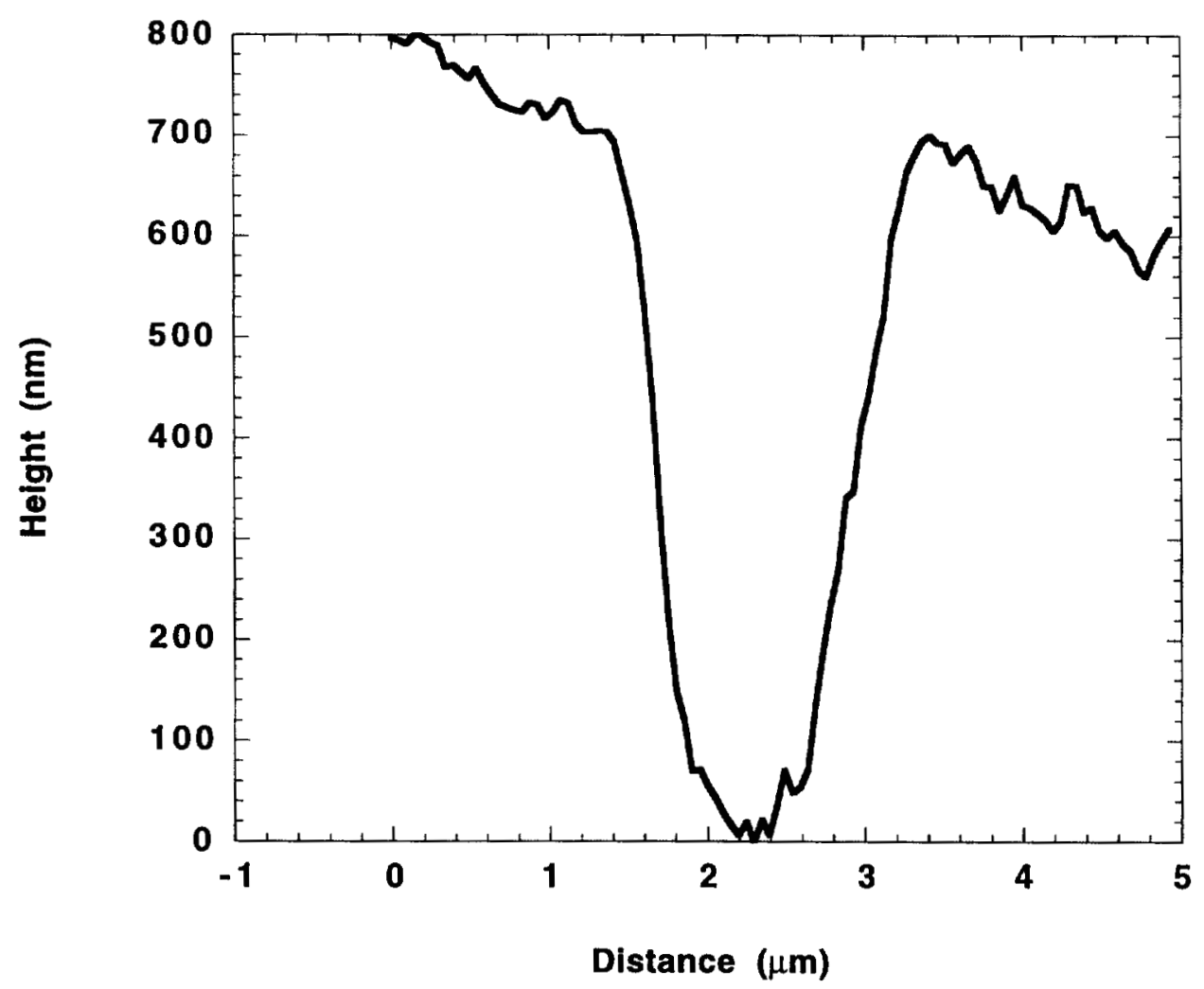

Figure 5: Profile of the depression in the lower left corner of the previous figure. 


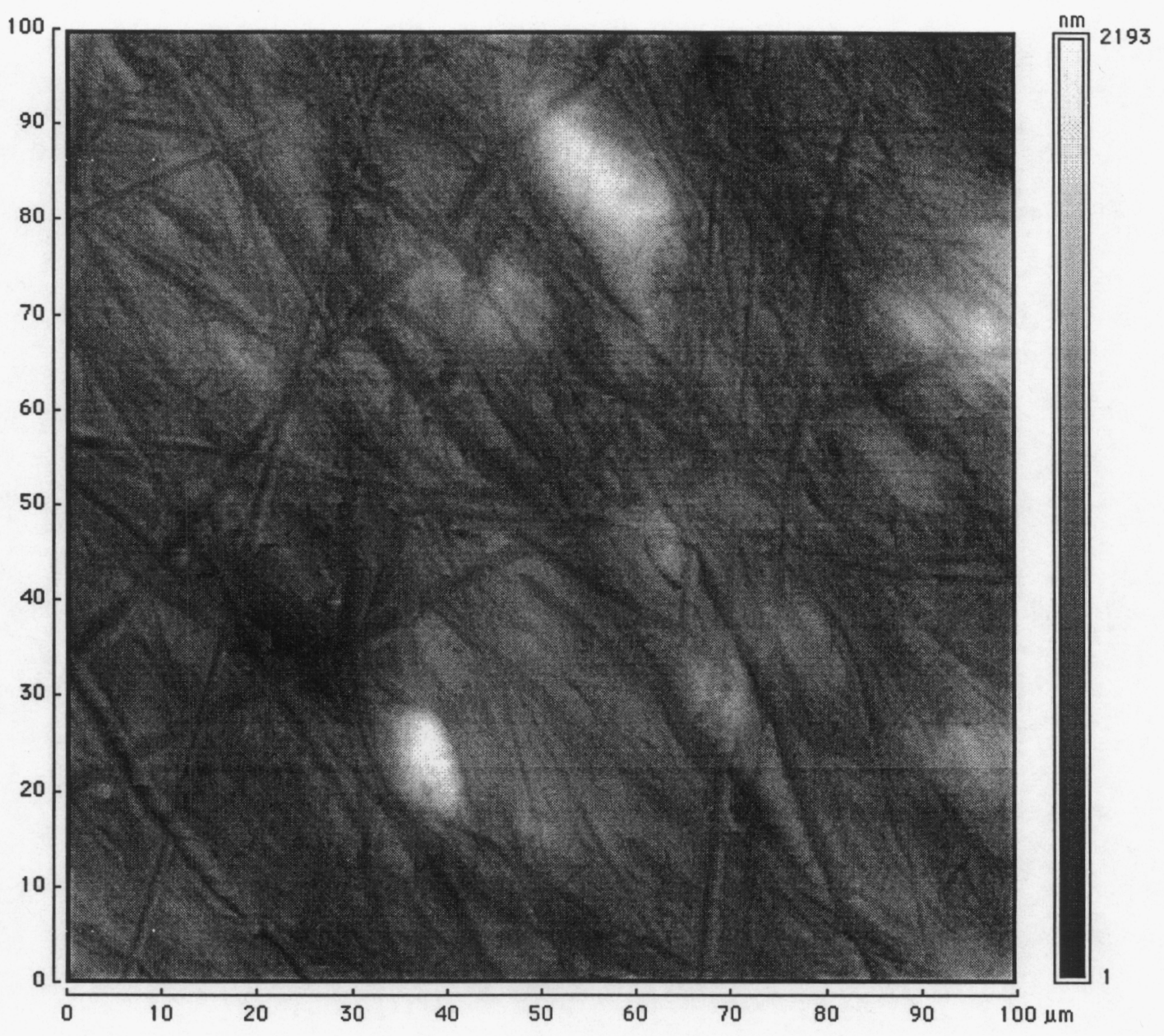

Figure 6: AFM image acquired 250 $\mu \mathrm{m}$ inside the crevice on the obverse side of coupon FCE106, immersed in 90C SCW for 2 years. (File 991127a.009) 


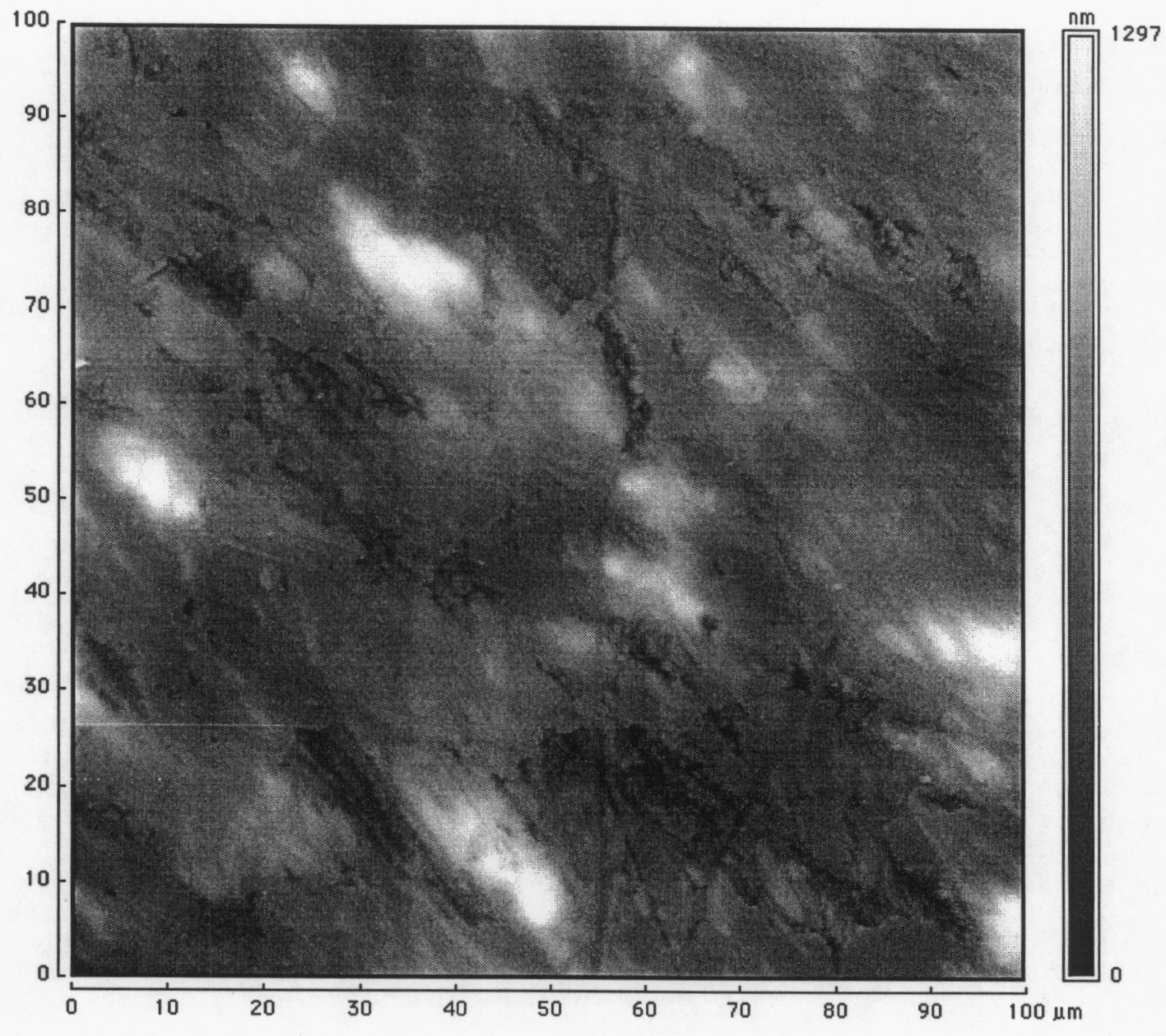

Figure 7: AFM image acquired 700 $\mu \mathrm{m}$ inside the crevice on the obverse side of coupon FCE106, immersed in 90C SCW for 2 years. (File 991127a.011) 


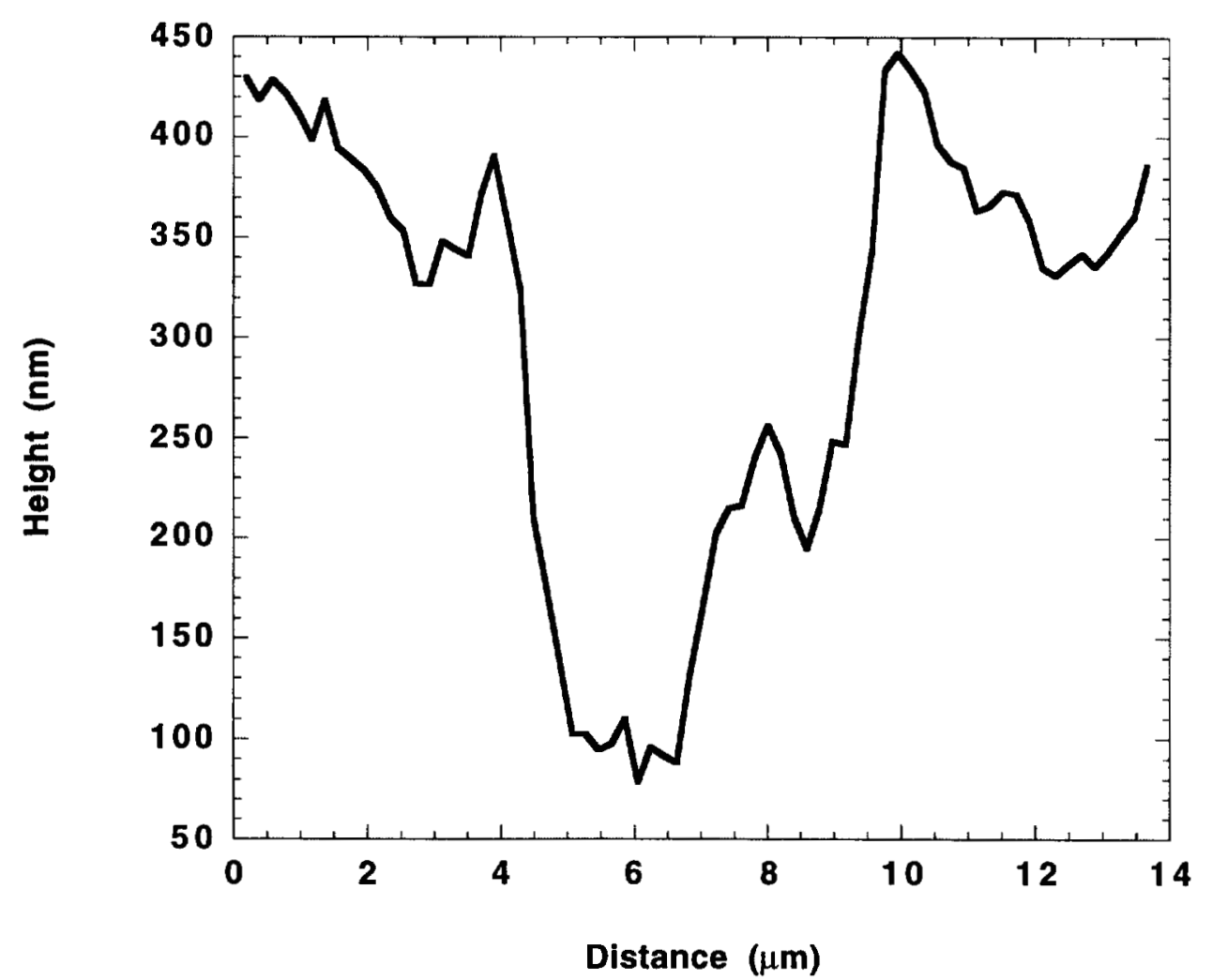

Figure 8: Profile through a depression in the lower right in the previous figure. 


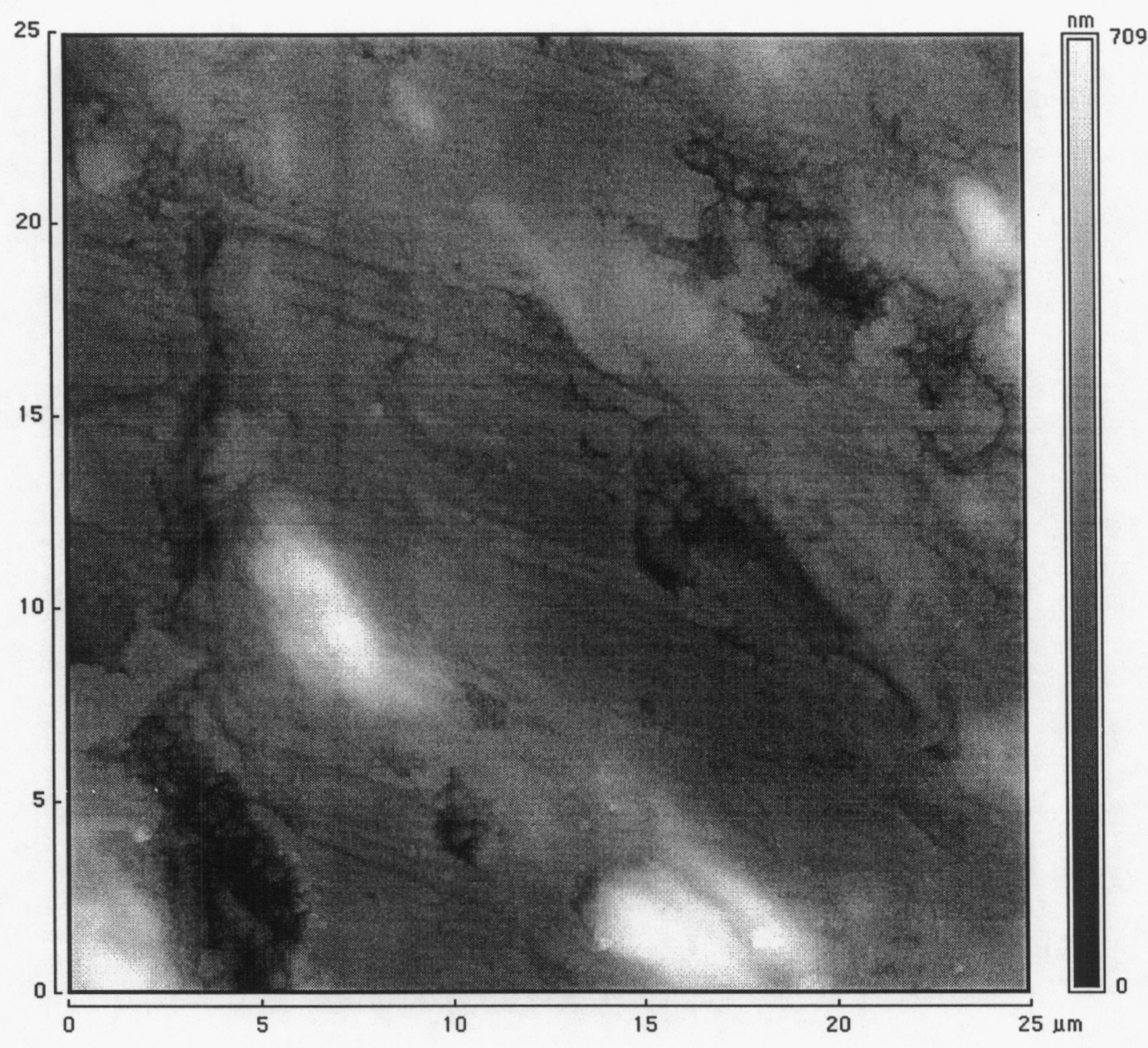

Figure 9: AFM image acquired $1.0 \mathrm{~mm}$ inside the crevice on the obverse side of coupon FCE106, immersed in 90C SCW for 2 years. (File 991127a.012) 


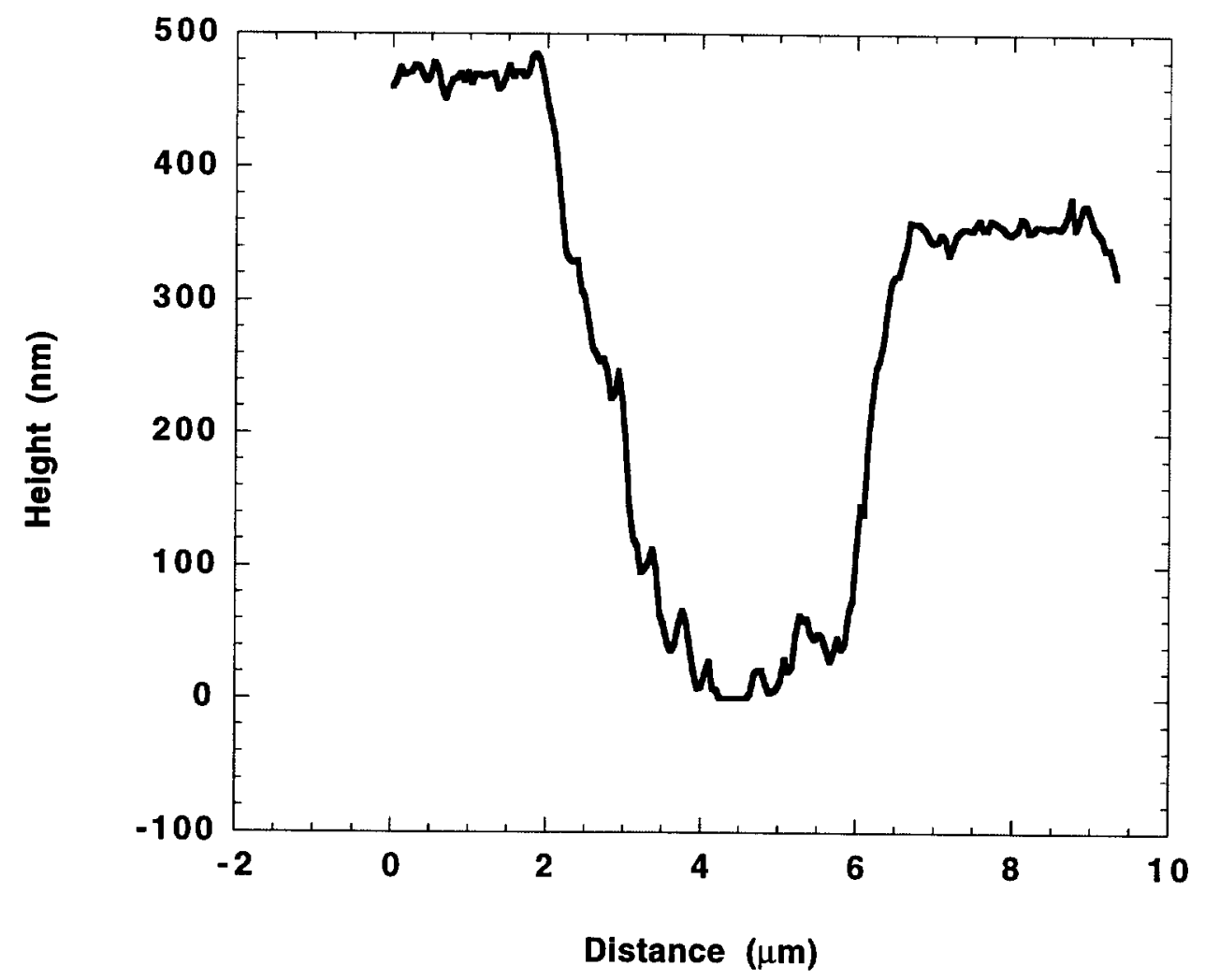

Figure 10: Profile through a depression in the upper right in the previous figure. 


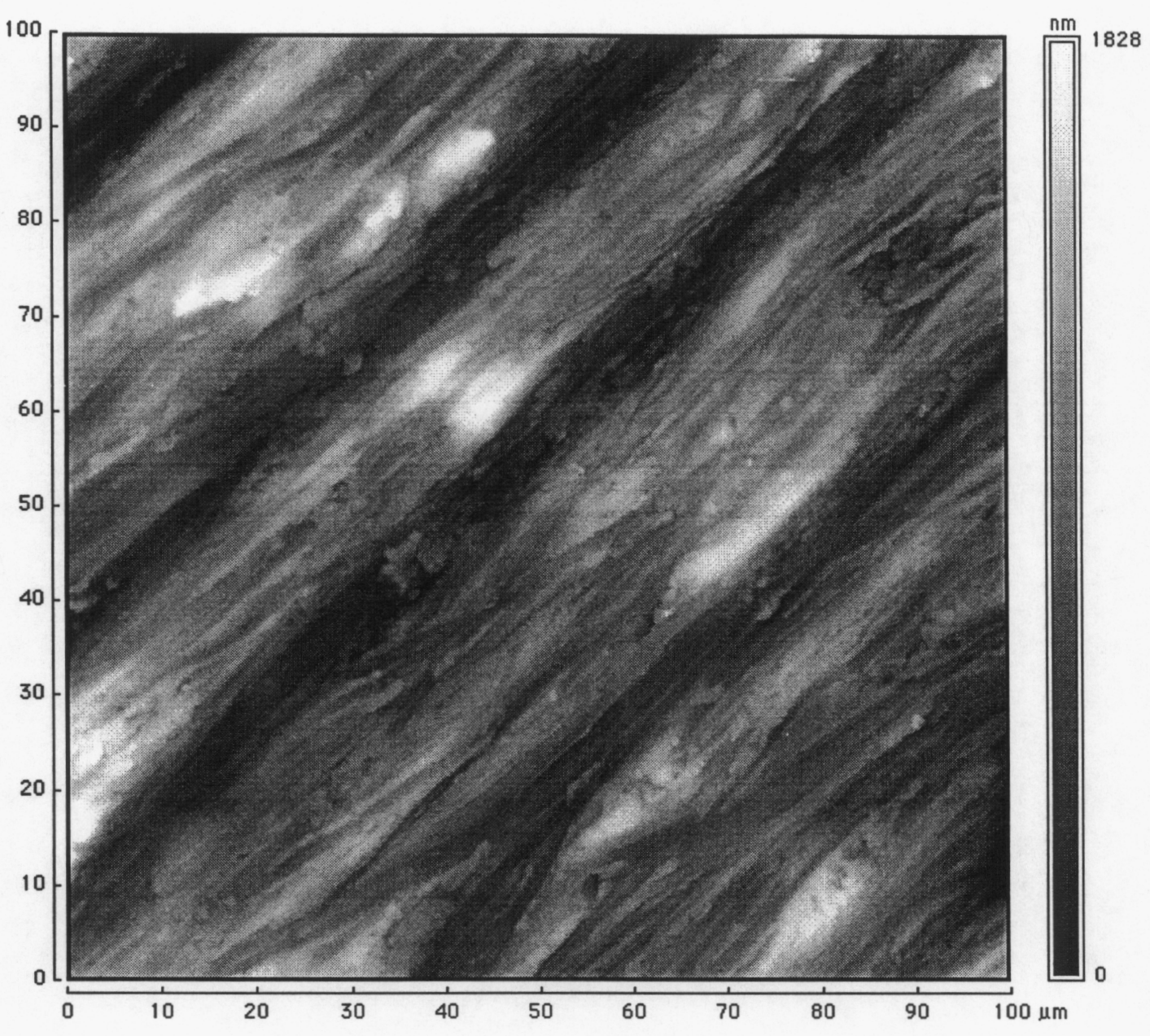

Figure 11: AFM image acquired inside the crevice on the obverse side of coupon FCE076, immersed in 60C SCW for 2 years. (File 991103a.003) 


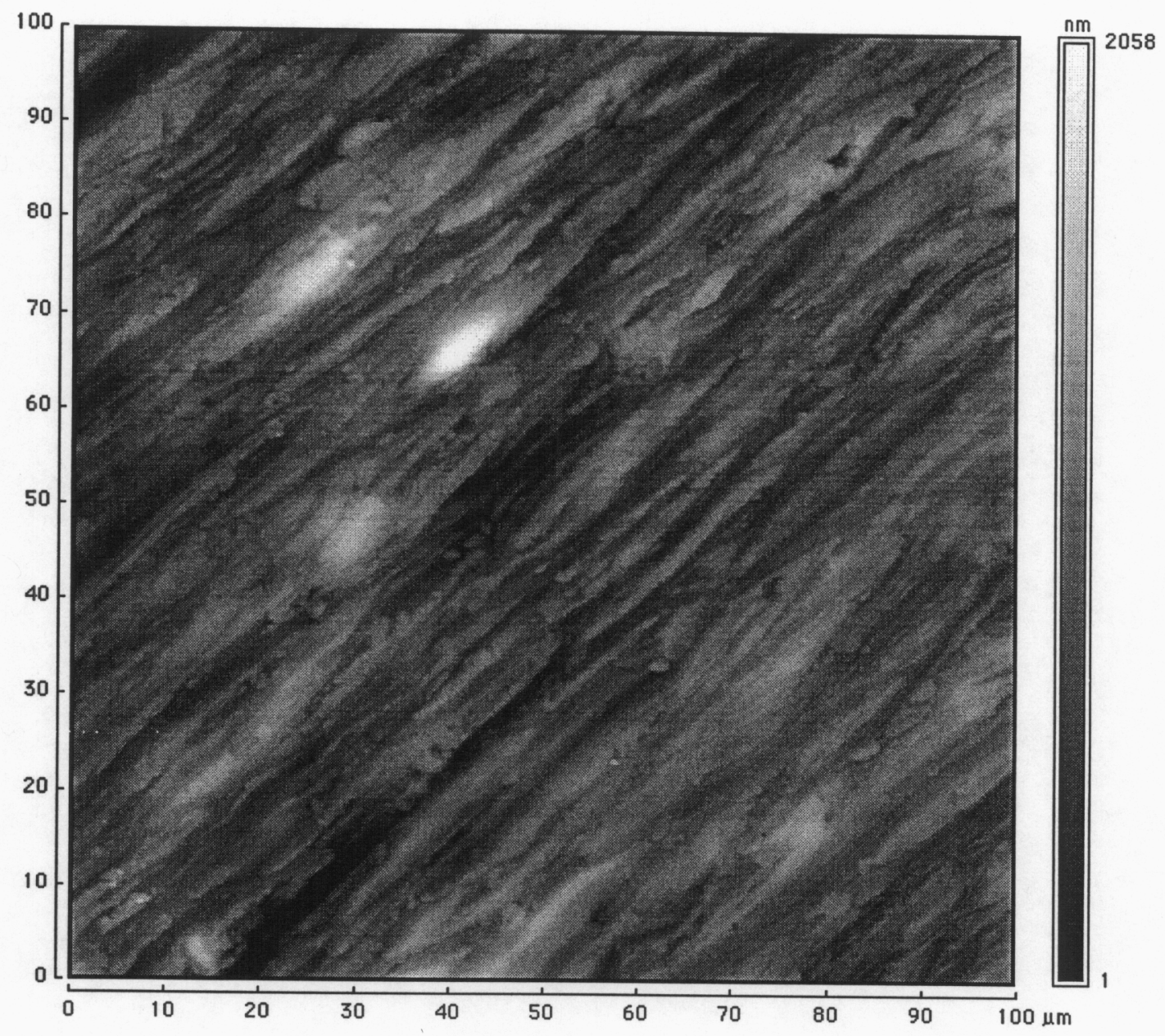

Figure 12: AFM image acquired at the crevice boundary on the obverse side of coupon FCE076, immersed in $60 \mathrm{C} \mathrm{SCW}$ for 2 years. The top is outside the crevice, and the lower half is inside the crevice.(File 991103a.005) 


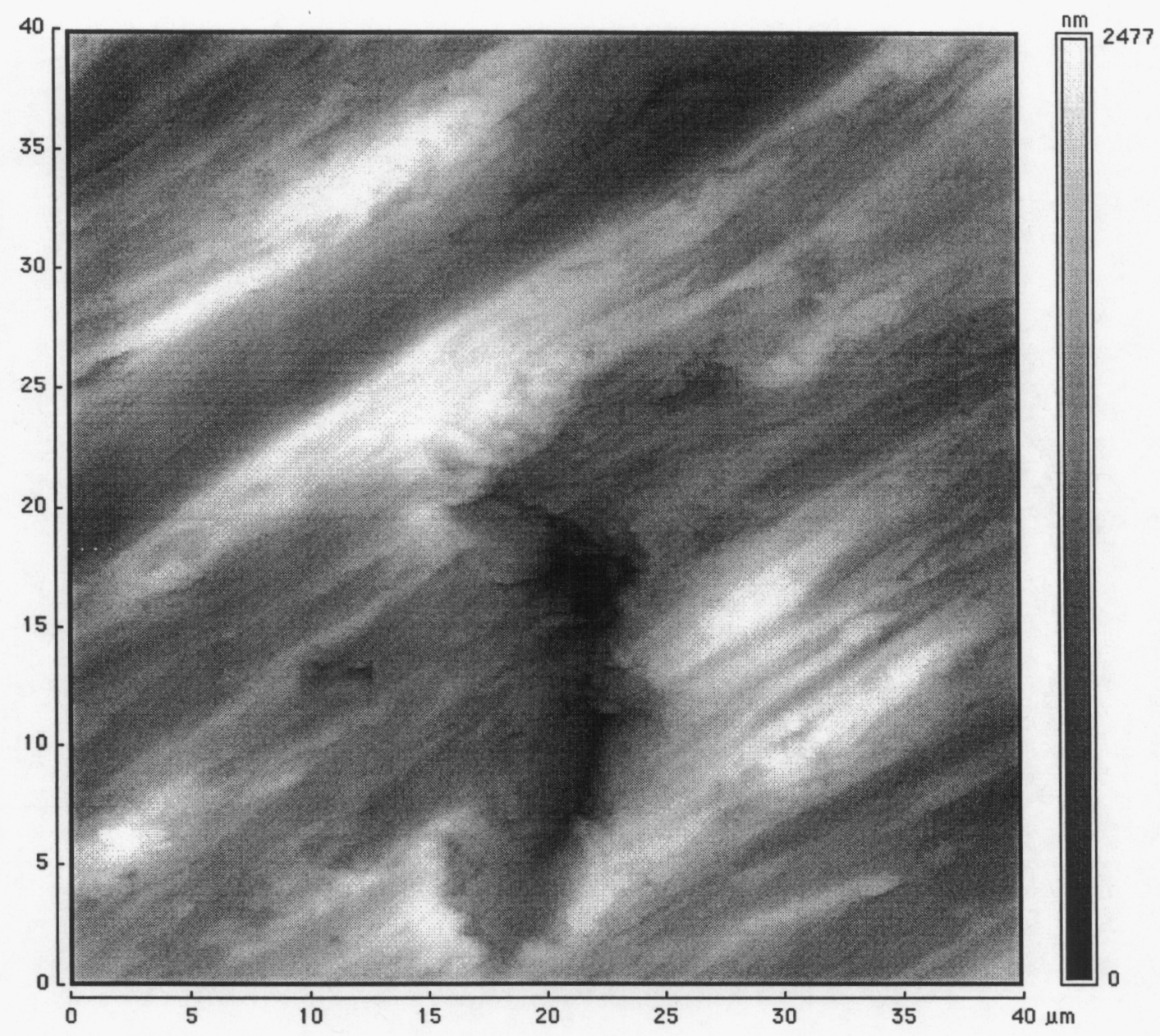

Figure 13: AFM image acquired outside the crevice on the obverse side of coupon FCE076, immersed in 60C SCW for 2 years. (File 991103a.007) 


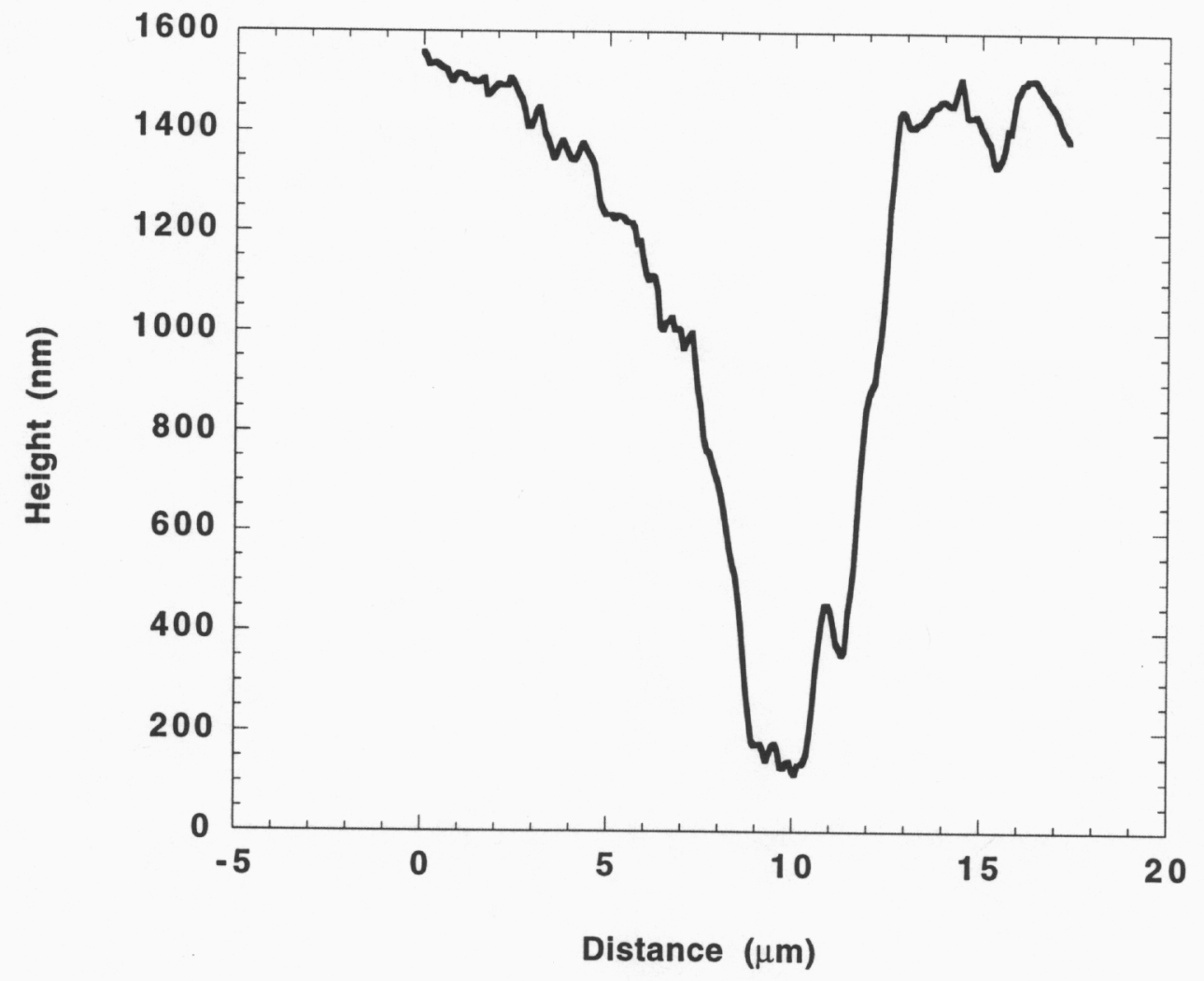

Figure 14: Profile plot across the prominent depression in the previous figure. 


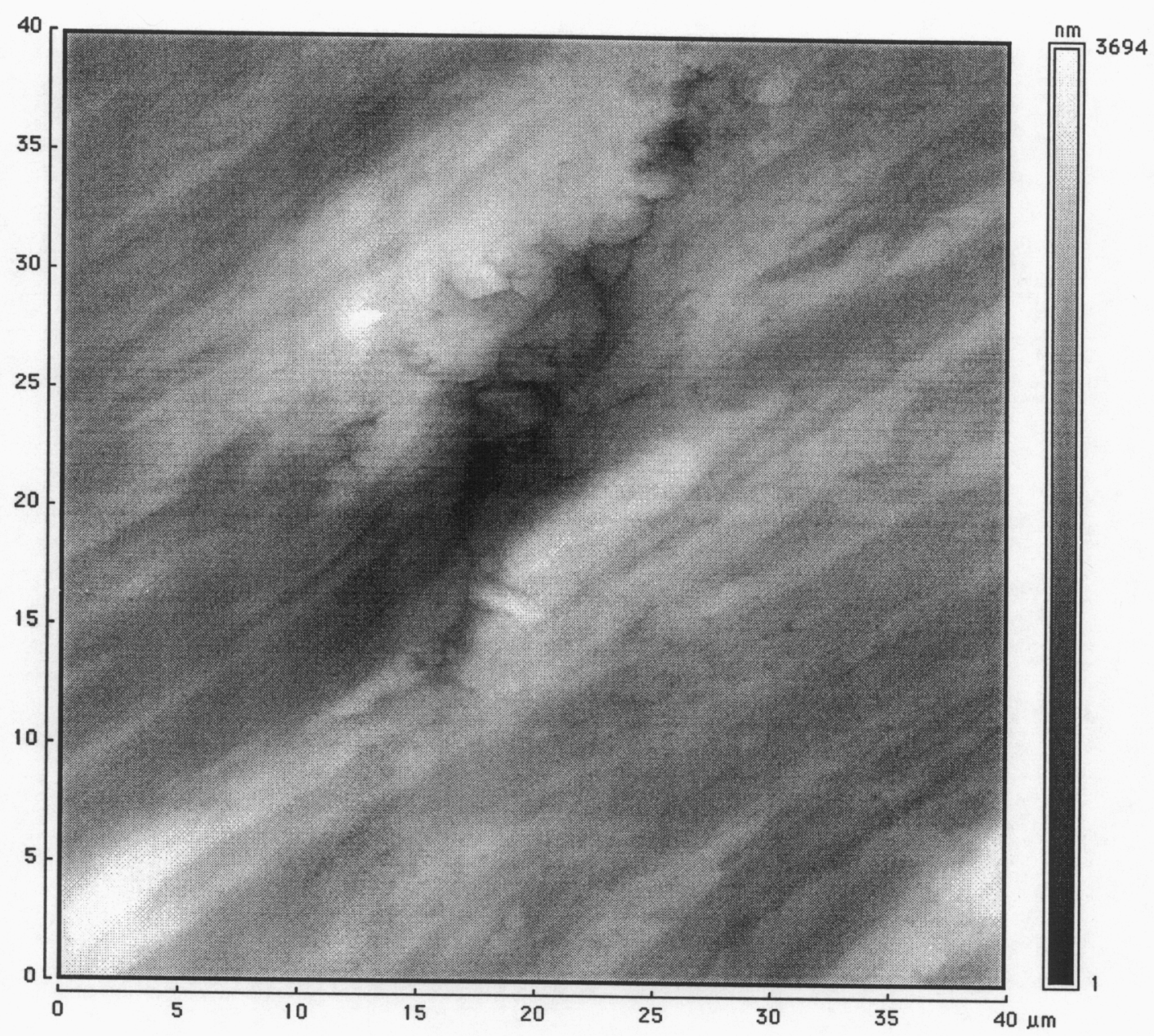

Figure 15: AFM image acquired outside the crevice on the obverse side of coupon FCE076, immersed in 60C SCW for 2 years. (File 991103a.009) 


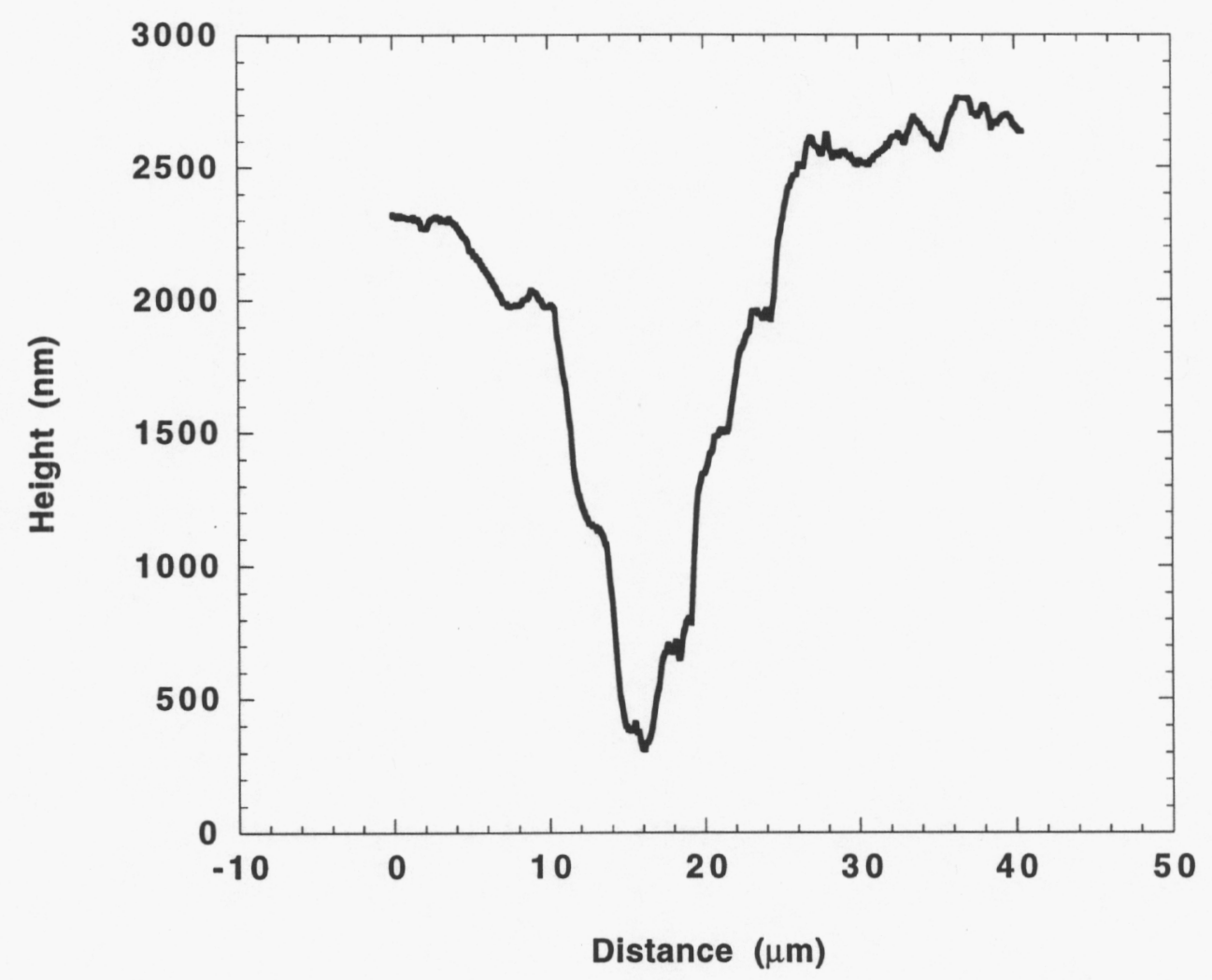

Figure 16: Profile plot across the prominent depression in the previous figure. 


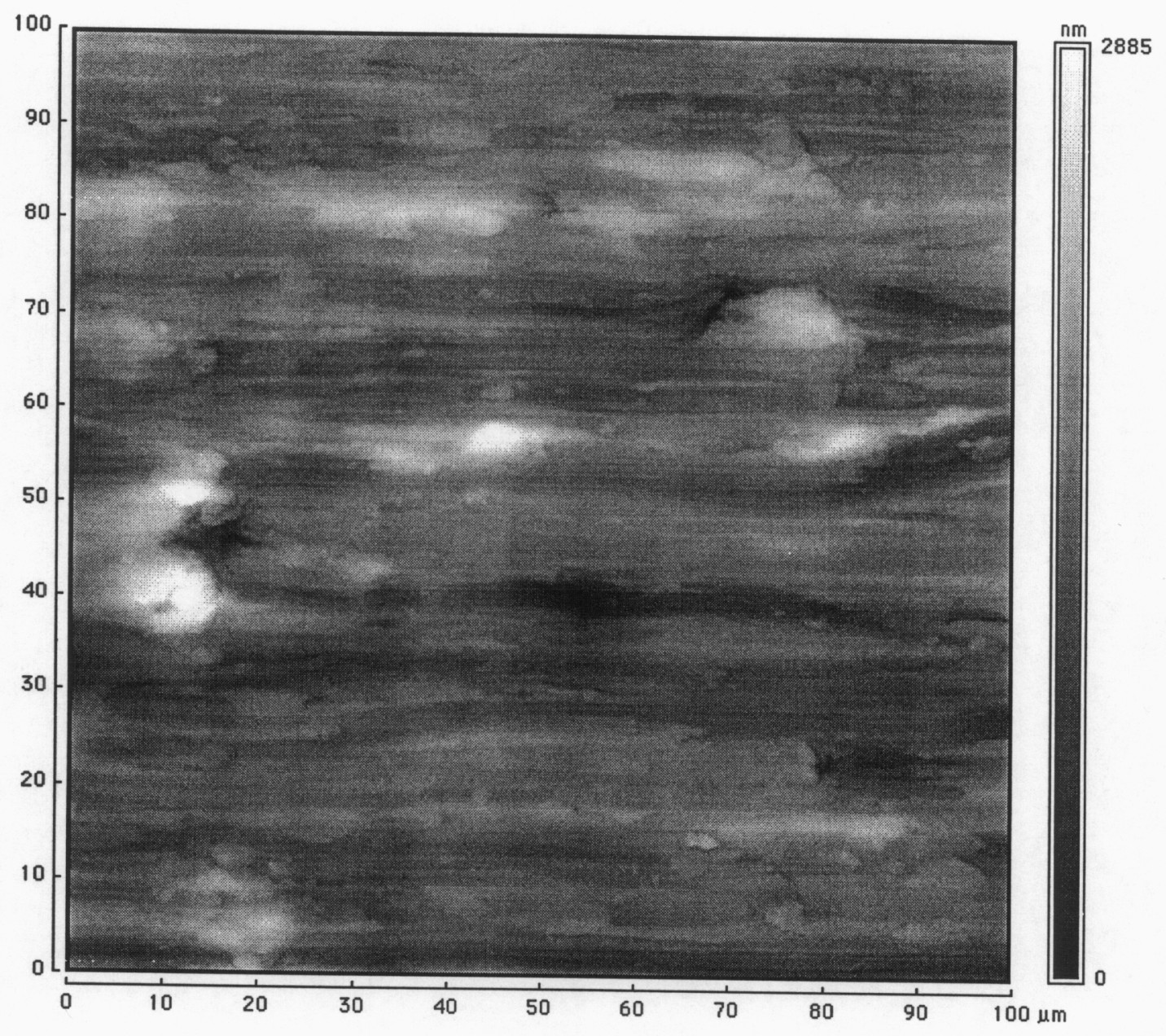

Figure 17: AFM image acquired outside the crevice on the obverse side of coupon FCE172, which was immersed in 90C SDW for 2 years. (File 991026a.010) 


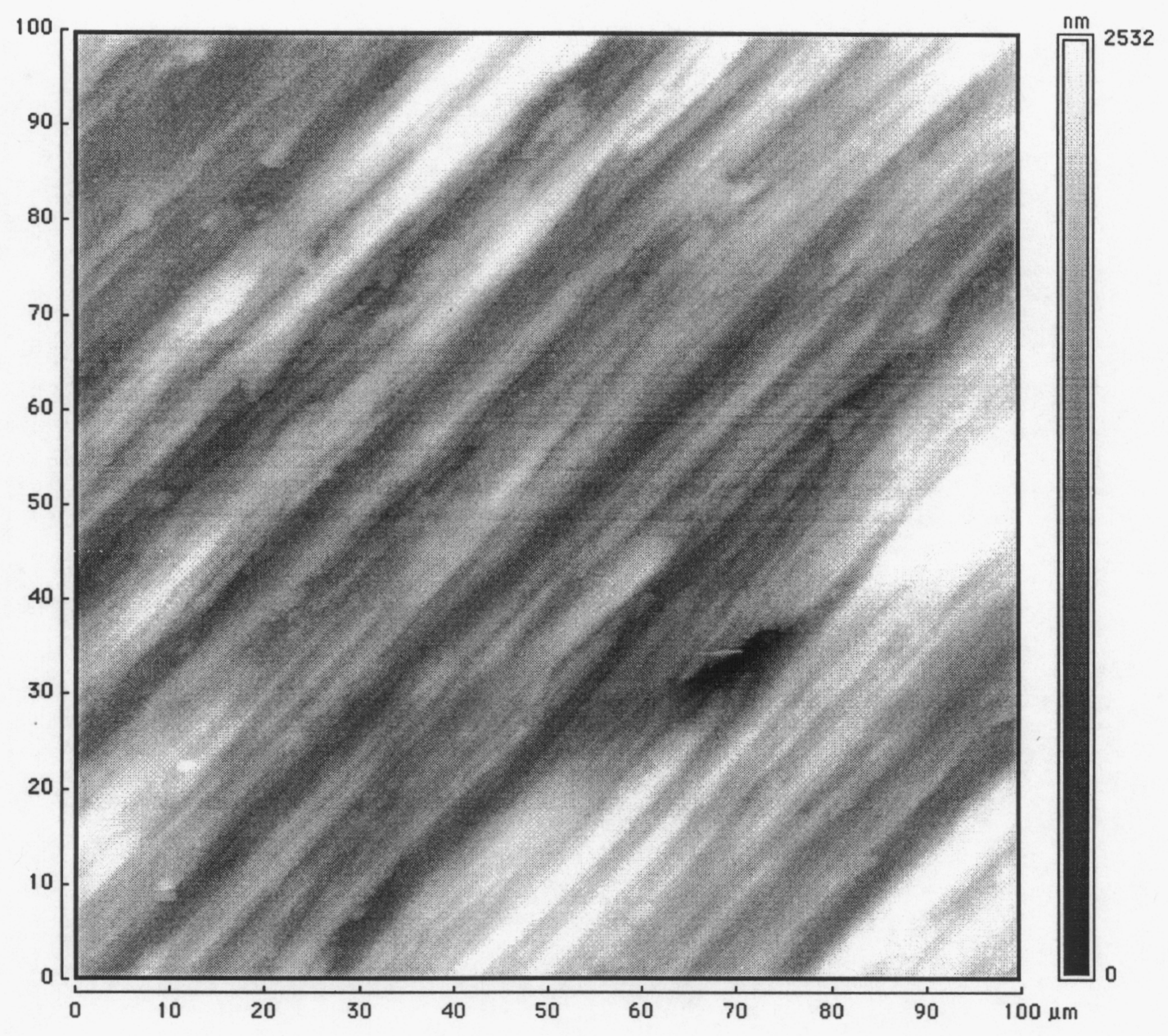

Figure 18: AFM image acquired inside the crevice of coupon FCE136, immersed in 60C SDW for 2 years. (File 991101a.001) 


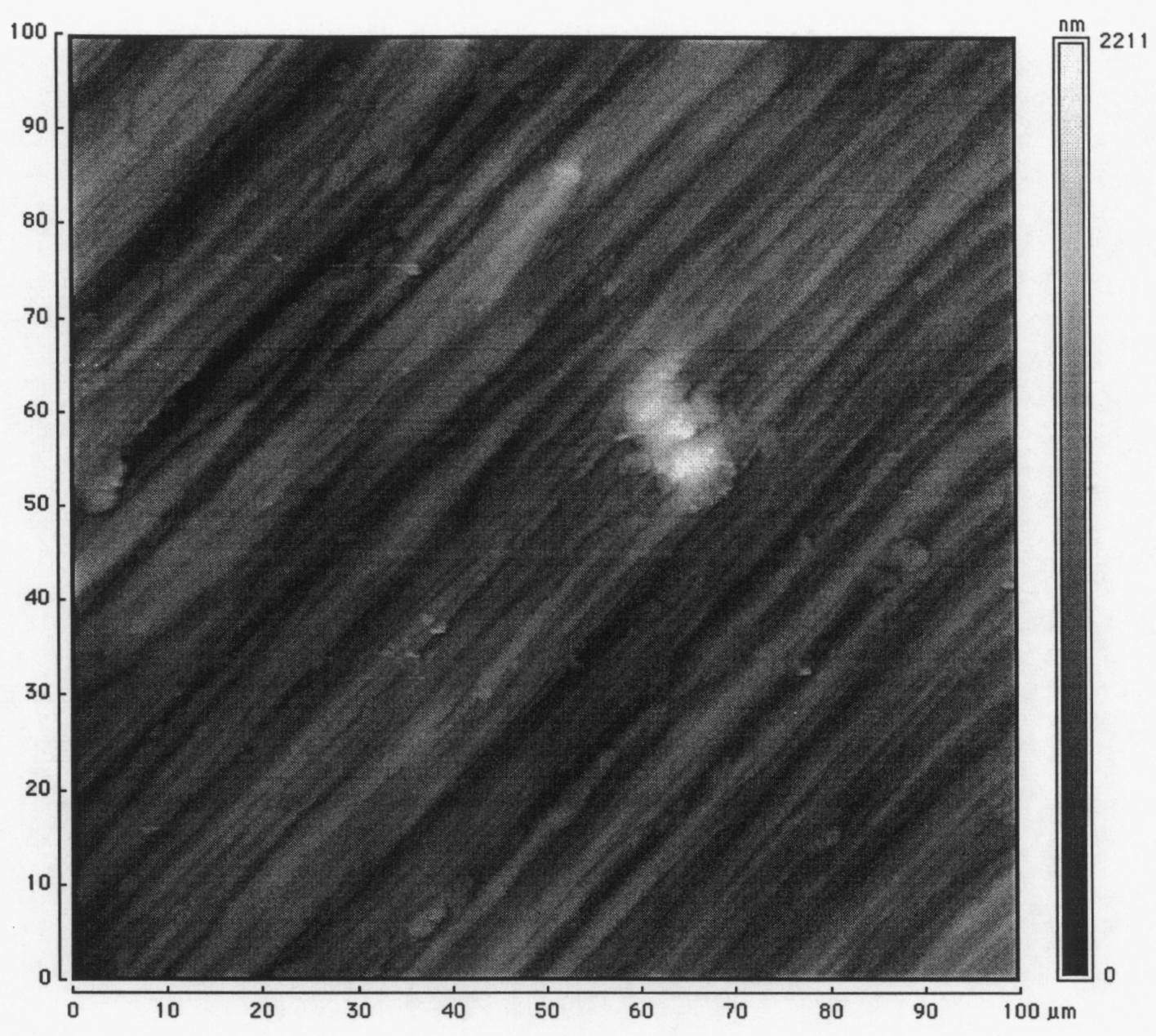

Figure 19: AFM image acquired outside the crevice of coupon FCE136, immersed in 60C SDW for 2 years. (File 991101a.001) 